\title{
Regeneration of Abies cephalonica Loudon after a Large Fire in Central Greece
}

\section{Yannis Raftoyannis ${ }^{1 \rrbracket}$, loannis Spanos ${ }^{2}$}

${ }^{1}$ Central Greece University of Applied Sciences, Department of Forestry, Demokratias 3, GR-36100 Karpenisi, Greece

${ }^{2}$ National Agricultural Research Foundation, Forest Research Institute, GR-57006 Vassilika, Thessaloniki, Greece

$\varangle$ Corresponding author: e-mail: rafto@teilam.gr

Citation:

RAFTOYANNIS Y, SPANOS I 2015 Regeneration of Abies cephalonica Loudon after a Large Fire in Central Greece. Southeast Eur for 6 (1): 5-14. DOI: http://dx.doi.org/10.15177/seefor.15-04

\section{Abstract}

Background and Purpose: Abies cephalonica Loudon (Greek fir) is a dominant tree species of the mountainous Greece that forms productive forests. Wildfires in fir forests were not considered a major threat but in recent decades, fir ecosystems in Greece have experienced large crown fires with subsequent ecological and economical losses.

Materials and Methods: This study was designed to aid our understanding of Greek fir recovery after fire. In Central Greece, 12 years after a large fire, fir regeneration and site factors were studied in 143 sampling plots located in 10 transects.

Results: Fir regeneration density decreased abruptly with distance from the remnant stands and followed the negative exponential curve with decreasing regeneration abundance from the border of the unburned zone. Abiotic factors such as elevation, aspect, slope steepness and ground cover type could not significantly explain any variability in fir regeneration density.

Conclusions: Our results showed that distance from a seed source was the most important variable in explaining fir regeneration. Moreover, the density of fir regeneration seemed adequate to provide stocking for a future fir forest.

Keywords: wildfire, seedling density, seed source, elevation, aspect, slope, groundcover

\section{INTRODUCTION}

Abies cephalonica Loudon (Greek fir) is widely distributed in the mountains of central and southern Greece, at altitudes between 700 and $1900 \mathrm{~m}$. Greek fir is a commercially valuable timber and fuel wood species that is also grown for Christmas trees and planted as an ornamental.

During most of the $20^{\text {th }}$ century, large fires in Greek fir forests were not a common observation. The complex topography and the 
high spatial heterogeneity of mountainous Greece, probably, resulted in variable fuels and burning conditions that favored a nonuniform fire behavior. Nevertheless, after many years of fire exclusion and land abandonment, Greek fir dominated and created pure stands, increasing the likelihood of large fires. Consequently, in recent years, the mountain forest ecosystems dominated by Greek fir are affected by an increasing number of wildfires of unusual size and severity [1].

This change in Greek fir fire trends could have been related to summer drought episodes that have increased in the relatively more humid and colder regions of Greece [2]. In the mountainous Mediterranean forests, alterations in composition and flammability trends are foreseen due to changes in drought stress and fire frequency [3]. For many mountain forests, fire is likely to become almost as important for shaping the landscape as the direct effects of climate change [4]. Paleoecological data show that the thermophilous Mediterranean fir stands became extinct during the last 5000 years when anthropogenic fire and browsing disturbance increased [5]. In many occasions, the fire-intolerant fir forests were replaced by fire-tolerant forest species like oaks and the current distribution of Abies species in Europe has been reduced in areas less affected by fire [6].

The fire traits of Greek fir include a thin and flammable bark that provides little insulation for the cambium, shallow roots which are susceptible to soil heating, low crown base branches and flammable foliage [2]. Moreover, Greek fir has a tendency to grow in dense stands, many of which are of old age and increased mortality episodes have resulted in large amounts of dead fuels.

Greek fir is vulnerable to fire as it does not produce serotinous cones and does not maintain a seed bank when summer wildfires occur [7]. Greek fir reaches reproductive maturity at around 50 years and cone production peaks at the age of 100-140 years. Seed availability varies considerably between years due to masting and seed dispersal usually begins in October. Since the window of opportunity for seedling establishment is short and germination rates are low, the first years after a fire are crucial for successful tree recruitment [8].

The response of fir ecosystems to fire may vary with fire frequency, size and severity, associated vegetation in the preand post-fire community, site conditions, distance to remnant stands, browsing and post-fire management. The rate of seedling establishment is quite variable and depends on the proximity of the seed source and seed production during the post-fire years [9]. Site conditions can be important during the early postfire years but tend to decrease with increasing time elapsed since fire, as canopy composition is getting more similar to pre-fire structure [9].

In many areas affected by stand-replacing fire, the natural return of fir forests is uncertain and opinions for postfire management differ. Arianoutsou et al. [10] concluded that the postfire recovery of Greek fir would be a slow process where unburned patches would play an important role. For the same site, Ganatsas et al. [11] suggested that without human intervention, shrubs and herbaceous species would dominate and planting could be the only solution for the reintroduction of Greek fir.

The capacity of Greek fir to regenerate after large stand-replacing fires is not well studied and this study was designed to aid our understanding of Greek fir recovery after fire with the aim to assist decision making in postfire management. The specific objectives were to evaluate the extent to which site factors affect fir regeneration after fire and identify the most important ones.

\section{MATERIALS AND METHODS}

\section{Site Description}

Our study area was located in the mountain fir forests of Central Greece $\left(39^{\circ} 04^{\prime} 40^{\prime \prime} \mathrm{N}\right.$, 
$\left.21^{\circ} 57^{\prime} 08^{\prime \prime} \mathrm{E}\right)$. The site has an oro-Mediterranean climate with cold and moist winters and relatively dry summers. The dry season lasts on average 2.5 months, from mid-June to the end of August. Meteorological data, for the last 18 years, from the nearby weather station

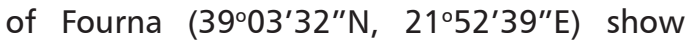
that the mean annual temperature was $10.7^{\circ} \mathrm{C}$ and the mean annual rainfall was $1131 \mathrm{~mm}$. The soils were mainly luvizols and acrisols developed on limestone and flysch.

Before fire, Greek fir was the dominant tree species while Juniperus oxycedrus L., Quercus frainetto Ten., Quercus pubescens Willd., Ilex aquifolium L. and Crataegus monogyna Jacq., were the main understorey woody species. The Greek fir tree $(\mathrm{dbh}>10 \mathrm{~cm})$ density of unburned stands was estimated from 13 randomly selected rectangular plots $(40 \times 10 \mathrm{~m})$ and resulted in a mean density of 1125 mature fir trees $\cdot \mathrm{ha}^{-1}$ (range 720-1634 trees $\cdot \mathrm{ha}^{-1}$ ).

On the $21^{\text {th }}$ of September 2000, a wildfire started and burned 3100 ha of fir forest. Immediately after fire, the burned trees were logged and the site was left to regenerate naturally without any planting. In the burned area most understory woody species regenerated by resprouting, with the exception of juniper, but their density was very low. After fire, the main herbaceous plants found in the burned area were Pteridium aquilinum (L.) Kuhn, Fragaria vesca L., Brachypodium sylvaticum (Huds.) Beauv., Digitalis ferruginea L., Hypericum perforatum L., and various species of Achillea, Aegilops, Agrostis, Bromus, Poa, Cirsium, Phlomus, Thymus, Trifolium and Vicia.

\section{Sampling Design}

In the summer of 2012, fir regeneration was recorded along 10 transects, following a systematic sampling where transects were separated by a distance of $100 \mathrm{~m}$. Each transect started from an unburned forest edge and extended into the burn at a right angle until the distance from a point in the fire perimeter was equal to the distance from the starting point of trasect (220-550 m). The center of the initial sampling plots was located $10 \mathrm{~m}$ away from the stems of the first remnant fir trees, in order to exclude any crown effect. Along transects, circular sampling plots of $5 \mathrm{~m}$ radius (area $=78.5 \mathrm{~m}^{2}$ ) were located every $30 \mathrm{~m}$, with a total of 143 .

At each sampling plot, fir regeneration was assessed by counting the number of wellestablished individual plants (height $>20 \mathrm{~cm}$ ). Furthermore, the dominant groundcover type was visually characterized at 10 points (every $1 \mathrm{~m}$ ) along the main $10 \mathrm{~m}$ diameter of each sampling plot and the results were transformed to percentages [12]. The four groundcover types were: 1) bare mineral soil or stones, 2) dead plant biomass (litter or downed herbs and trees), 3) other competing vegetation (herbaceous or woody plants), 4) fir plants. Furthermore, in each sampling plot, we recorded the distance from a seed source $(m)$, slope steepness (\%), prevailing aspect (North, East, South, West) and elevation (meters above sea level) with the aid of a measure tape, GPS, clinometer, compass and a laser distance meter (LaserAce, MDL, UK).

\section{Data Analysis}

The relationship between postfire fir recruitment and site factors (distance from seed source, altitude, slope steepness, aspect and groundcover) was investigated using linear regression analysis. Fir seedling density data were positively skewed and were log $(x+1)$ transformed to meet the distributional assumptions. Model selection was performed using the Best Subsets tool of MINITAB 15 statistical software (Minitab Inc., State College, PA). Best Subsets compares all possible models using a specified set of predictors, and displays the best-fitting models that contain one predictor, two predictors, and so on. Analysis of variance followed by the Tukey's multiple comparison test were used to identify significant differences in seedling densities at various distances from the seed source. Analyses were conducted at a significance level $p<0.05$. 


\section{RESULTS}

Regression analysis showed that only the distance to seed source was a significant and important predictor of fir regeneration density. This model explained $54 \%$ of the variation in the response variable. Adding more predictors to the model did not improve it. The model was: $\log ($ Seedling density +1$)=3.6719-0.004806$ Distance $(m)$ from seed source.

Further regression analyses using the residuals of the main analysis and the other site factors as predictors resulted in models that explained very low percentages of the variation in seedling density and are not presented here.

Fir regeneration followed a negative exponential decline with distance from seed source (Figure 1). Overall, the mean density of fir was 1436 seedlings.ha-1 (range 0-13843 seedlings $\cdot \mathrm{ha}^{-1}$ ) and fir seedlings were found in $92 \%$ of the sampling plots. The analysis of variance revealed significant differences in seedling concentrations at various distances from the seed source. Ten meters away from the seed source, the mean density of fir seedlings was 10084 seedlings ha $^{-1}$ (range 5207-13843). At $40 \mathrm{~m}$ from the seed source, the mean number of fir seedling dropped sharply to 2591 seedlings $\cdot \mathrm{ha}^{-1}$, then at $70 \mathrm{~m}$ to 1791 seedlings $\cdot \mathrm{ha}^{-1}$ and at $100 \mathrm{~m}$ to 1435 seedlings ha $^{-1}$. Beyond $100 \mathrm{~m}$, the distance from seed source no longer resulted in significant differences in seedling density. Mean fir densities remained above 1000 seedlings ha $^{-1}$ up to $130 \mathrm{~m}$ and dropped below 500 seedlings ha $^{-1}$ beyond $220 \mathrm{~m}$ from seed source. Almost half of fir seedlings (49\%) were found in the initial sampling plots at $10 \mathrm{~m}$ from the seed source while $70 \%$ of the total number of seedlings occurred within $70 \mathrm{~m}$ from the remnant stands.

The mean altitude of all sampling plots was $1305 \mathrm{~m}$ (range 1179-1399 m) while half of the sampling plots were located in a small altitudinal range of only $50 \mathrm{~m}$ (1300-1350 m) (Figure 2). High seedling densities were observed above $1330 \mathrm{~m}$ and low below $1250 \mathrm{~m}$ a.s.l.. Slope steepness varied from 0 to $47 \%$ (mean $24 \%$ ) and no clear effect on fir regeneration density could be detected (Figure 3). Aspect had no

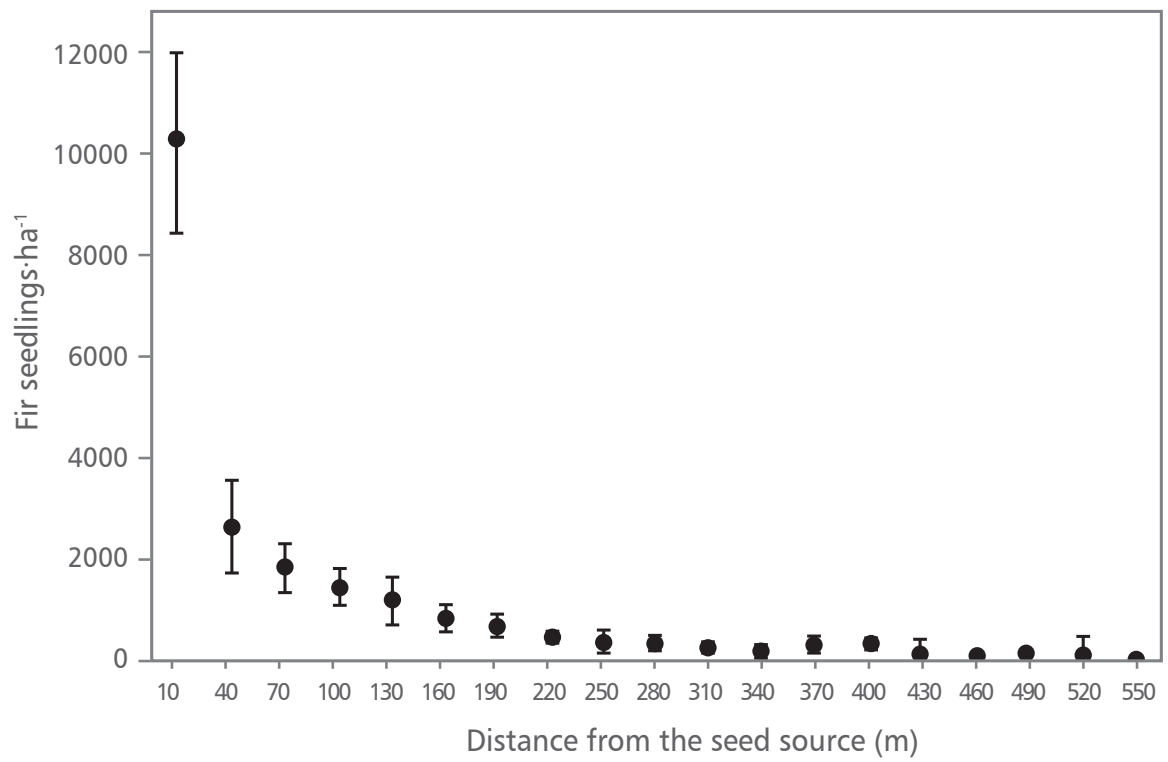

FIGURE 1. Fir seedling densities observed at various distances from the seed source. Dots represent the mean with $95 \%$ confidence intervals. 
clear effect on fir regeneration density while most sampling plots were located on southern aspects and very few on western aspects (Figure 4).

Groundcover type was not an important predictor of fir regeneration. High fir regeneration densities were recorded mainly in the sampling plots with $10 \%$ of exposed soil or rocks (Figure 5). Most of the high seedling densities were observed in sampling plots that were covered by litter or woody debris at $20 \%$. High fir seedling densities were observed in the few sampling plots with low competition from other vegetation.

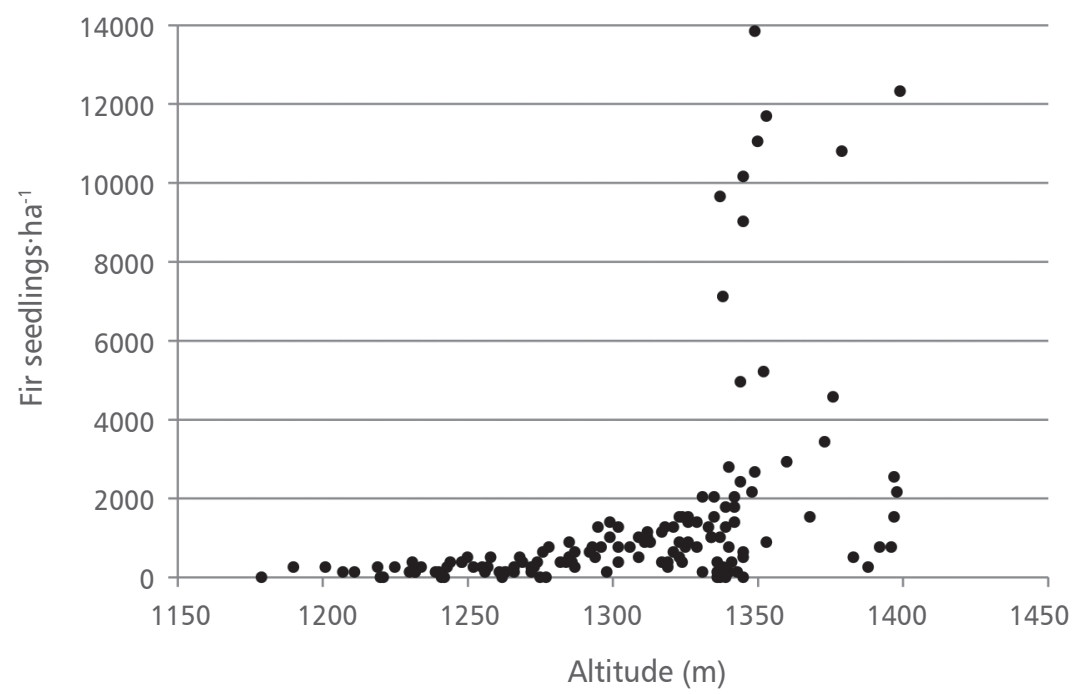

FIGURE 2. Scatterplot of fir seedling densities against altitude above sea level

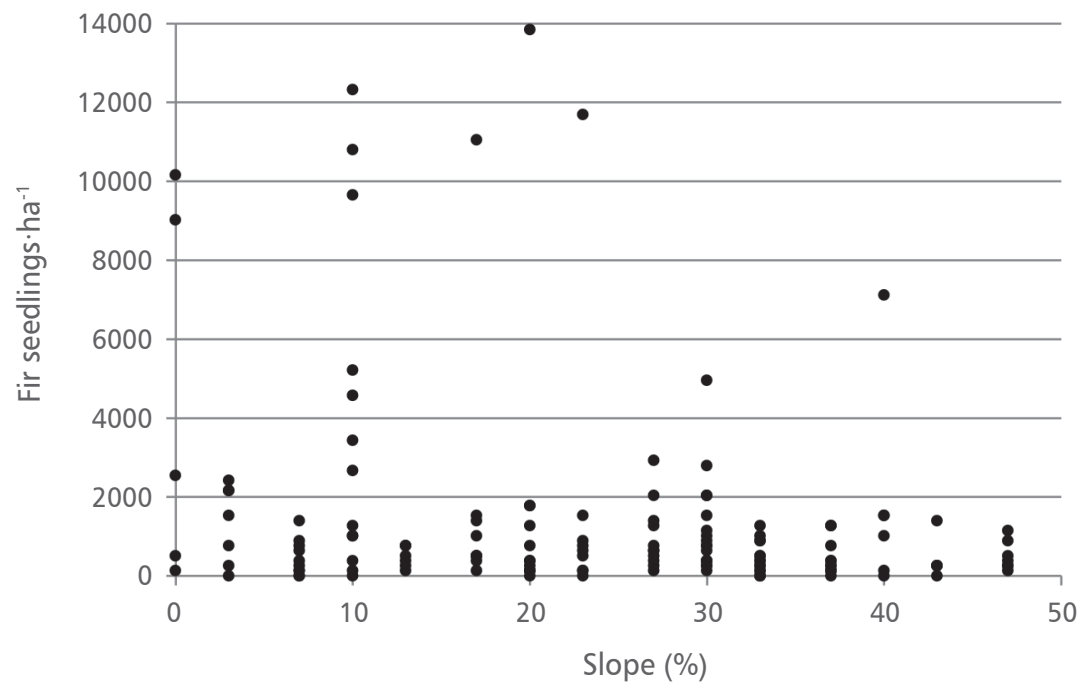

FIGURE 3. Fir seedling densities observed at different slope gradients. Dots represent individual values. 


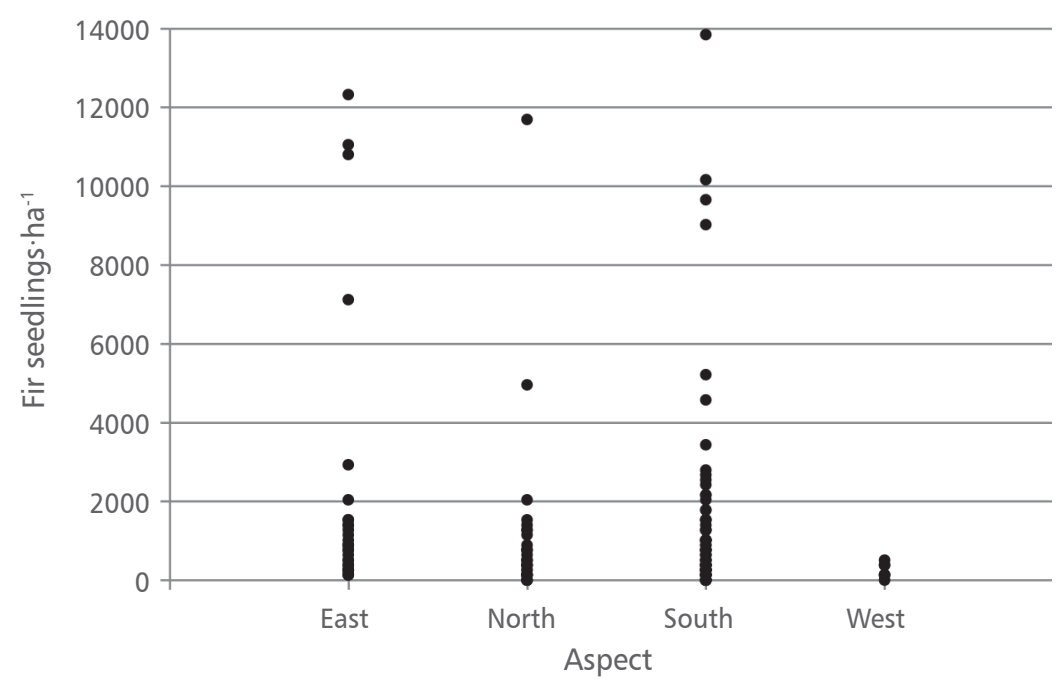

FIGURE 4. Fir seedling densities observed at different aspects. Dots represent individual values.

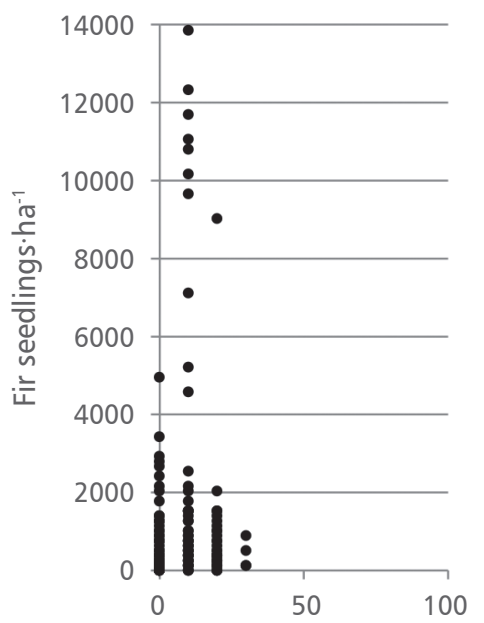

Exposed soil or rock cover (\%)

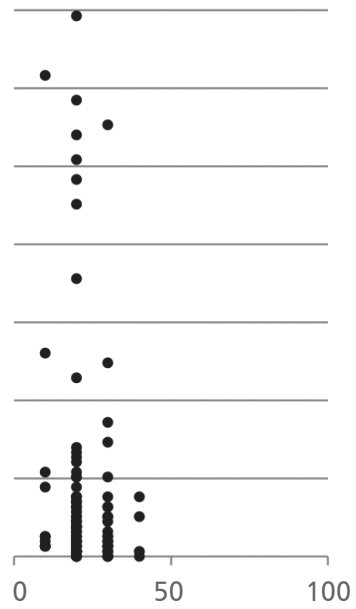

Dead plant biomass cover (\%)

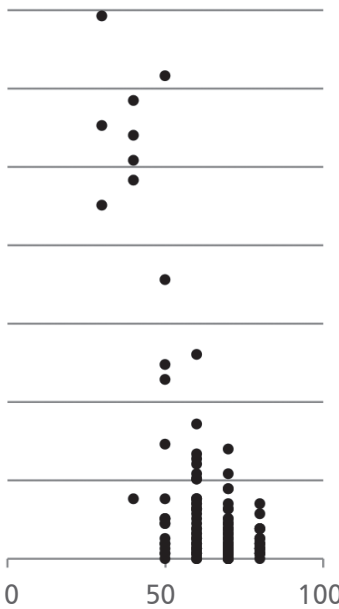

Other vegetation cover (\%)

FIGURE 5. Fir seedling densities observed at different levels of groundcover type (exposed soil or rock, dead plant biomass, other vegetation). Dots represent individual values.

\section{DISCUSSION}

In this study, the distance from a seed source was the most important variable in explaining fir regeneration when compared to other site variables, a common observation in similar studies [13, 14]. Greek fir regeneration density decreased abruptly with distance from remnant stands and followed the negative exponential curve with decreasing regeneration abundance from the border of the unburned zone, a typical pattern of postfire fir regeneration 
$[12,15]$. Mature trees that survive fire and remnant stands are the only seed sources for colonization of burned sites [16] and the high concentration of seedlings near the remnant stands is a common observation for nonserotinous conifers [14].

Twelve years after fire, the mean density of fir seedlings was 1436 stems.ha ${ }^{-1}$ which is close to and even higher than the fir density of the surrounding unburned stands $\left(1125\right.$ stems $\cdot$ ha $\left.^{-1}\right)$. Similar studies report a mean seedling density from 362 stems $\cdot \mathrm{ha}^{-1}$ [17] to 1603 stems $\cdot$ ha $^{-1}$ [18]. However, two studies on Greek fir regeneration reported that, 2 and 3 years after fire, no fir seedlings were observed although a considerable amount of healthy seeds was counted on the ground at distances up to $70 \mathrm{~m}$ from remnant trees $[11,16]$. It seems that time since fire is positively correlated with seedling abundance for late successional conifer species such as firs that will dominate in the absence of fire [19]. Fir seedlings, usually, establish within 5 years of the fire [20] and while fir recruitment can be low during the first 50 years, it increases to higher levels thereafter by advancing waves of regeneration when the pioneering firs mature $[21,22]$.

Although seedling density is higher at forest edges, the natural fir regeneration can be abundant at distances greater than $200 \mathrm{~m}$ or $400 \mathrm{~m}$ from a seed source before declining farther away $[18,23,24]$. In our site, the mean fir densities remained above 500 seedlings $\cdot$ ha $^{-1}$ up to $220 \mathrm{~m}$ from the remnant stands and even at distances greater than $400 \mathrm{~m}$, some fir seedlings were recorded. The observed seedling densities could lead to the creation of a mature fir forest within 50 years after fire that will cover most of the burned area. By the end of this century, the whole burned area is expected to be naturally reforested and occupied by a mature fir forest.

The relationship between fir regeneration and altitude was difficult to interpret, as many environmental variables covaried with altitude, the altitude range was small (almost $200 \mathrm{~m}$ ) and the high seedling densities observed in the higher altitudes were mainly due to their proximity to seed sources. Post-fire conifer regeneration usually increases across the elevation gradient, possibly due to increasing moisture availability as a result of an increase in precipitation and decrease in temperature at higher elevations [8, 17, 25]. Moreover, slope steepness was not considered an important abiotic factor of fir regeneration as has also been reported elsewhere $[18,19]$.

Aspect had no clear effect on fir regeneration density and it was not an important predictor as has also been reported by Donato et al. [18]. However, other studies show that a northern aspect favors fir regeneration $[22,26]$. Moisture stress can be a critical factor limiting conifer regeneration in dry coniferous forests and is usually higher in sites of high solar radiation $[14,17,21,25)$. Our observations can be partially explained due to the fact that Greek fir is considered one of the best drought-adapted European firs [27]. Moreover, our site was not a dry area but a relatively moist one with high rainfall and deep soils that can support good fir regeneration even in areas with high solar radiation.

Fir regeneration was high in locations with a low percentage of exposed soil or rocks. Seed germination and seedling survival after disturbance are generally favored by a thin organic layer and exposed mineral soil [28]. However, such seedbeds are usually found in the interior of a fire, away from the seed source which is the most important variable affecting fir regeneration [29]. As a result, tree recruitment can be even negatively related to the availability of exposed mineral soil in the first years after fire [25].

The effect of dead plant biomass on fir regeneration was not clear although most high seedling densities were observed in sampling plots covered with litter or woody debris at $20-30 \%$. Following fire, fir establishment can be higher near woody debris than other microsite features [21]. The positive impact of coarse woody debris on plant regeneration can be attributed to its protective role from high temperatures and excessive water loss [14].

Greek fir establishment was low where 
the herbaceous and woody plant cover was dense. The competing vegetation were mainly herbaceous plants and after fire the window of opportunity for conifer recruitment was probably very short as the rapid spread of herbaceous species increased competition and reduced the availability of favorable seedbeds [25].

\section{CONCLUSIONS}

In conclusion, after a large stand-replacing fire, Greek fir regeneration depended mainly on the distance from seed source. Abiotic factors such as elevation, aspect, slope steepness and ground cover type could not significantly explain any variability in fir regeneration density.
Moreover, the density of fir regeneration seemed adequate to provide stocking for a future fir forest. However, our conclusions are valid only for our site, one of the best sites for fir growth in Greece. In less favorable areas, fir regeneration could be delayed or possibly replaced by shrubs or hardwoods.

\section{Acknowledgements}

This research has been co-financed by the European Union (European Social Fund - ESF) and Greek national funds through the Operational Program "Education and Lifelong Learning" of the National Strategic Reference Framework (NSRF) - Research Funding Program: ARCHIMEDES III, Investing in knowledge society through the European Social Fund.

\section{REFERENCES}

1. ARIANOUTSOU M, LEONE V, MOYAD, LOVREGLIOR, DELIPETROU P, DE LAS HERAS J 2012 Management of Threatened, High Conservation Value, Forest Hotspots Under Changing Fire Regimes. In: Moreira F, Arianoutsou M, Corona P, De las Heras $\mathrm{J}$ (eds) Post-Fire Management and Restoration of Southern European Forests, Springer, Dordrecht, The Netherlands, pp 257-291. DOI: http://dx.doi. org/10.1007/978-94-007-2208-8_ 11

2. DIMITRAKOPOULOS AP, VLAHOU $M$, ANAGNOSTOPOULOU CG, MITSOPOULOS ID 2011 Impact of drought on wildland fires in Greece: Implications of climatic change? Climatic Change 109 (3-4): 331-347. DOI: http://dx.doi. org/10.1007/s10584-011-0026-8

3. FYLLAS NM, TROUMBIS AY 2009 simulating vegetation shifts in north-eastern Mediterranean mountain forests under climatic change scenarios. Glob Ecol Biogeogr 18 (1): 64-77. DOI: http:// dx.doi.org/10.1111/j.1466-8238.2008.00419.x

4. SCHUMACHER S, BUGMANN H 2006 The relative importance of climatic effects, wildfires and management for future forest landscape dynamics in the Swiss Alps. Global Change Biol 12 (8): 14351450. DOI: http://dx.doi.org/10.1111/j.13652486.2006.01188.x
5. TINNER W, COLOMBAROLI D, HEIRI O, HENNE PD, STEINACHER M, UNTENECKER J, VESCOVI E, ALLEN JRM, et al. 2013 The past ecology of Abies alba provides new perspectives on future responses of silver fir forests to global warming. Ecol Monogr 83 (4): 419-439. DOl: http://dx.doi. org/10.1890/12-2231.1

6. TINNER W, HUBSCHMID P, WEHRLI M, AMMANN B, CONEDERA M 1999 Long-term forest fire ecology and dynamics in southern Switzerland. J Ecol 87 (2): 273-289. DOI: http://dx. doi.org/10.1046/ j.1365-2745.1999.00346.x

7. POLITI PI, GEORGHIOU K, ARIANOUTSOU M 2011 Reproductive biology of Abies cephalonica Loudon in Mount Aenos National Park, Cephalonia, Greece. Trees 25 (4): 655-668. DOI: http://dx.doi. org/10.1007/s00468-011-0542-1

8. POLITI PI, ARIANOUTSOU M, STAMOU GP 2009 Patterns of Abies cephalonica seedling recruitment in Mount Aenos National Park, Cephalonia, Greece. Forest Ecol Manag 258 (7): 1129-1136. DOI: http:/l dx.doi.org/10.1016/j.foreco.2009.05.038

9. DE GRANDPRE L, MORISSETTE J, GAUTHIER S 2000 Long-term post-fire changes in the northeastern boreal forest of Quebec. J Veg Sci 11 (6): 791-800. DOI: http://dx.doi.org/10.2307/3236549 
10. ARIANOUTSOU M, CHRISTOPOULOU A, KAZANIS D, TOUNTAS TH, GANOU E, BAZOS I, KOKKORIS Y 2010 Effects of fire on high altitude coniferous forests of Greece. In: Viegas DX (ed) Book of Proceedings of the $\mathrm{VI}^{\text {th }}$ International Conference of Forest Fire Research, Coimbra, Portugal, 15-18 November 2010. University of Coimbra, Coimbra, Portugal. URL: http://www.uaeco.edu.gr/files/PDF/ int conf proc/41 Arianoutsou et al.2010.pdf (12 December 2014)

11. GANATSAS P, DASKALAKOU E, PAITARIDOU D 2012 First results on early post-fire succession in an Abies cephalonica forest (Parnitha National Park, Greece). iForest-Biogeosciences and Forestry 5: 6-12. DOI: http://dx.doi.org/10.3832/ifor0600$\underline{008}$

12. RAFTOYANNIS Y, SPANOS I 2005 Evaluation of log and branch barriers as post-fire rehabilitation treatments in a Mediterranean pine forest in Greece. Int J Wildland Fire 14 (2): 183-188. DOI: http://dx.doi.org/10.1071/WF04031

13. ASSELIN H, FORTIN MJ, BERGERON Y 2001 Spatial distribution of late-successional coniferous species regeneration following disturbance in southwestern Québec boreal forest. Forest Ecol Manag 140 (1): 29-37. DOI: http://dx.doi. org/10.1016/S0378-1127(00)00273-5

14. CHRISTOPOULOU A, FYLLAS NM, ANDRIOPOULOS $P$, KOUTSIAS N, DIMITRAKOPOULOS PG, ARIANOUTSOU M 2014 Post-fire regeneration patterns of Pinus nigra in a recently burned area in Mount Taygetos, Southern Greece: The role of unburned forest patches. Forest Ecol Manag 327 (1): 148-156. DOI: http://dx.doi.org/10.1016/j. foreco.2014.05.006

15. GREENE DF, JOHNSON EA 1996 Wind dispersal of seeds from a forest into a clearing. Ecology 77 (2): 595-609. DOI: http://dx.doi.org/10.2307/2265633

16. ARIANOUTSOU M, CHRISTOPOULOU N, GANOU E, KOKKORIS Y, KAZANIS D 2009 Post-fire response of the Greek endemic Abies cephalonica forests in Greece: the example of a NATURA 2000 site in Mt Parnitha National Park. In: Miko L, Boitani L (eds) Book of Abstracts of the 2nd European Congress of Conservation Biology: "Conservation biology and beyond: from science to practice", Prague, Czech Republic, 1-5 September 2009. Czech University of Life Sciences, Faculty of Environmental Sciences, Prague, Czech Republic, pp 52. URL: http://www.carnivoreconservation. org/files/meetings/eccb 2009.pdf (11 December 2014)
17. DODSON EK, ROOT HT 2013 Conifer regeneration following stand-replacing wildfire varies along an elevation gradient in a ponderosa pine forest, Oregon, USA. Forest Ecol Manag 302 (15): 163-170. DOI: http://dx.doi.org/10.1016/i. foreco.2013.03.050

18. DONATO DC, FONTAINE JB, CAMPBELL JL, ROBINSON WD, KAUFFMAN JB, LAW BE 2009 Conifer regeneration in stand-replacement portions of a large mixed severity wildfire in the Klamath-Siskiyou Mountains. Can J Forest Res 39 (4): 823-838. DOI: http://dx.doi.org/10.1139/X09016

19. KNEESHAW DD, BERGERON Y 1996 Ecological factors affecting the abundance of advance regeneration in Quebec's southwestern boreal forest. Can J Forest Res 26 (5): 888-898. DOI: http://dx.doi.org/10.1139/x26-097

20. JOHNSON CG 1998 Vegetation response after wildfires in national forests of northeastern Oregon.US Department of Agriculture, Forest Service, Pacific Northwest Region, Portland, OR, USA, $128 p$

21. LITTLE RL, PETERSON DL, CONQUEST LL 1994 Regeneration of subalpine fir (Abies lasiocarpa) following fire: effects of climate and other factors. Can J Forest Res 24 (5): 934-944. DOI: http:// dx.doi.org/10.1139/x94-123

22. GALIPEAU C, KNEESHAW D, BERGERON Y 1997 White spruce and balsam fir colonization of a site in the southeastern boreal forest as observed 68 years after fire. Can J Forest Res 27 (2): 139-147. DOI: http://dx.doi.org/10.1139/x96-148

23. SHATFORD JPA, HIBBS DE, PUETTMANN KJ 2007 Conifer regeneration after forest fire in the Klamath-Siskiyous: How much, how soon? J Forest 105 (3): 139-146

24. HARPER KA, DRAPEAU P, LESIEUR D, BERGERON Y 2014 Forest structure and composition at fire edges of different ages: Evidence of persistent structural features on the landscape. Forest Ecol Manag 314 (15): 131-140. DOI: http://dx.doi. org/10.1016/j.foreco.2013.12.009

25. MOSER B, TEMPERLI C, SCHNEITER G, WOHLGEMUTH T 2010 Potential shift in tree species composition after interaction of fire and drought in the Central Alps. Eur J For Res 129 (4): 625-633. DOI: http://dx.doi.org/10.1007/s10342$\underline{010-0363-6}$ 
26. ESTEBAN LG, DE PALACIOS P, RODRIGUEZ-LOSADA AGUADO L 2010 Abies pinsapo forests in Spain and Morocco: threats and conservation. Oryx 44 (2): 276-284. DOI: http://dx.doi.org/10.1017/ $\underline{\text { S0030605310000190 }}$

27. AUSSENAC G 2002 Ecology and ecophysiology of circum-Mediterranean firs in the contexts of climate change. Ann For Sci 59 (8): 823-832. DOI: http://dx.doi.org/10.1051/forest:2002080
28. VALKONEN S, MAGUIRE DA 2005 Relationship between seedbed properties and the emergence of spruce germinants in recently cut Norway spruce selection stands in southern Finland. For Ecol Manag 210 (1-3): 255-266. DOI: http://dx.doi. org/10.1016/j.foreco.2005.02.039

29. GREENE DF, MACDONALD SE, CUMMING S, SWIFT L 2005 Seedbed variation from the interior through the edge of a large wildfire in Alberta. Can J Forest Res 35 (7): 1640-1647. DOI: http:// dx.doi.org/10.1139/x05-080

(C) 2015 by the Croatian Forest Research Institute. This is an Open Access paper distributed under the terms of the Creative Commons Attribution License (http://creativecommons.org/licenses/by/4.0). 